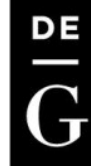

DOI 10.2478/pesd-2014-0036

PESD, VOL. 8, no. 2, 2014

TYPES AND FORMS OF RELIEF ON GHERASIM TORRENTIAL VALLEY, TÂRGU OCNA

\author{
Mară, $\mathbf{M}^{1}$, Dârlău, Oana ${ }^{2}$ \\ Key words: types and forms of relief, Gherasim torrential valley, Târgu Ocna
}

\begin{abstract}
The present study brings new data regarding the landforms occurring on gypsum rocks through the action of denudation processes. The landforms signaled complement the domain literature with natural dams, vertical shafts and reappearing springs, developed at the contact between the Subcarpathians and Berzunţi Mts. The presence of the gypsum dam has slowed down the intensity of erosion processes upstream, in comparison to the neighboring valleys. The analyzed area has also an educational importance, offering sufficient objectives for the knowledge of the local characteristics or for field applications. The perimeter presents sufficient objectives also to be included on the list of protected areas of national interest.
\end{abstract}

\title{
Introduction
}

\subsection{Scientific and practical importance}

The study and putting into circuit of geographical knowledge on the fields situated in the North-West side of Târgu Ocna town has imposed by the originality of forms of relief present, which are related to the presence of plasters in the lithology of the area. Their high friability and solubility determines a rapid damage of the petrographic relief formed on these rocks. The reduced thickness of plaster layers and their position from the contact between mountains and Subcarpathians facilitate a large extension of denudation processes that determine a rapid damage of these forms of relief. The perpendicular position of plaster and freestone layers, compared to the discharge direction of Gherasim valley, allowed the individualisation of a natural levee, the waters discharged on the versants of Gherasim valley infiltrating through a sink-hole positioned at the upstream basis of the natural levee and the infiltrated waters get out through a Karstic intermittent spring at an altitude lower by $28 \mathrm{~m}$ from the sink-hole. In the upper part of the

\footnotetext{
${ }^{1}$ Phd.mara.marin@yahoo.com

${ }^{2}$ General School no. 79, Bucharest
} 
natural levee there is a dissolution doline, with the diameter of $9 \mathrm{~m}$ and with a depth of $2 \mathrm{~m}$. We can observe the multitude and diversity of forms presented in this space of only 8 ha, which confers it a didactic importance (for pupils and students) and for tourism.

The preservation of functionality of this natural levee is also important for the preservation of current ecosystems upstream the natural levee (forests and grasslands), by the creation of a local base level, which, compared to Nistoroaia valley from the West side of the natural levee, is higher by at least $20 \mathrm{~m}$.

\subsection{Geographical positions and limits}

The studied sector is situated between $26^{\circ} 35^{\prime} 11^{\prime \prime}$, and $26^{\circ} 11^{\prime}$ '33' east longitude and $46^{\circ} 18^{\prime} 24^{\prime}$ 'și $46^{\circ} 18^{\prime} 40^{\prime \prime}$ North latitude and represents a torrential valley without permanent discharge, developed at the contact of Carpathian orogen to the neogene one. The transom we refer is delimited at the north side by Gherasim Hill, continued towards east by a saddle which makes the pass towards Nistoroaia peak. From this limit peak, it orients towards south, on the crest and the south versant, up to the confluence of the three brooks, Rugiului, Nistoroaia and Gherasim, and the west limit is represented by Nistoroaia torrential valley.

The catchment basin of Gherasim valley is placed on the submontane glacis below Ceir Peak and is drained towards Vâlcele brook, affluent of Trotuş on the left side (Fig. 1, Fig. 2).

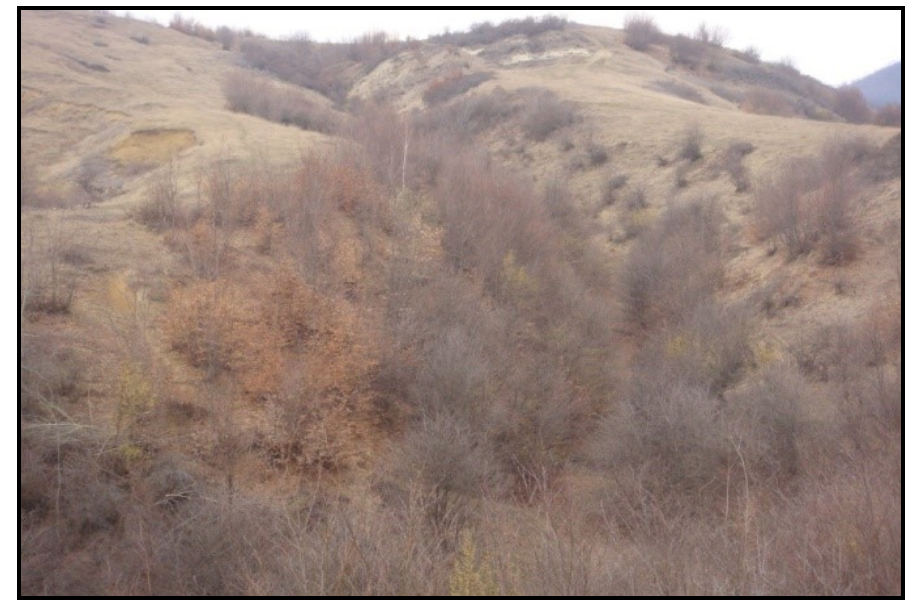

Fig. 1. Gherasim torrential valley, upstream the natural levee.

\subsection{Research history}

In the country, the presence of karstic relief composed by plasters was signalled by various geographers. The most frequent forms of relief are the lapiès, 
the dolines and the wadis, with a strictly punctual extension.

Grigore Posea and collab. (1976) signals that on plaster, salt, sulphur and other sulphides, lapiès, dolines and uvalas are formed at the surface, and in the interior part, small hollows and karstic grottos, to which is also added a specific morphology, conditioned by human intervention (pits, fallen salt pits, wells, galleries). Traian Naum and Mihai Grigore, (1974), highlight the plaster relief in the following locations:

- on Valea Stânii of Mezeșului Mountains, there are present lapiès with crests smaller than $2 \mathrm{~cm}$ and 2 dolines, of which the largest in the form of an elongated ellipsis signalled I.Viehmann and I. Mac (1966);

- in the vicinity of Cheia Village (Cheile Turzii), on the saddle between Hășdatelor Valley and Valea Lungă, dolines with diameter of $100 \mathrm{~m}$ and a depth of $15 \mathrm{~m}$ are present;

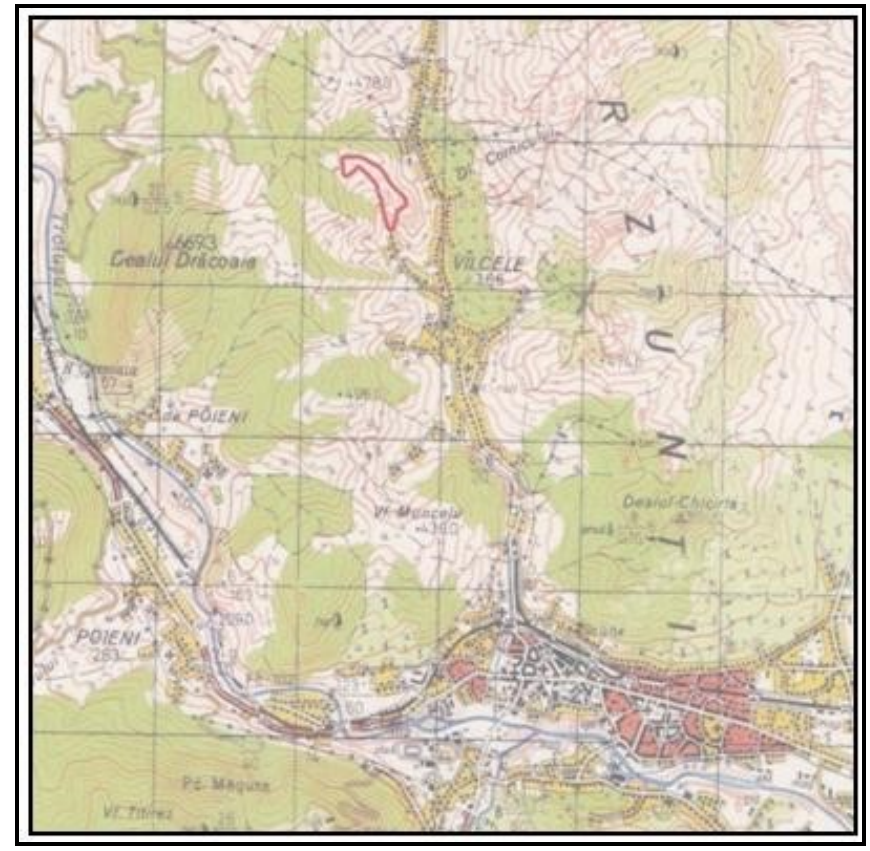

Fig. 2. Location sketch Gherasim torrential valley.

V. Trufaș (quoted by Naum and Grigore, 1974) signals the presence of some dolines and slopes developed at the contact between Muscelele Argeșului and the crystalline of Făgăraș Mountains, on the interfluves between Vâlsanului Valley and Râul Doamnei. Dolines are signalled at "Găurile Șteurului" and variable dimension dolines are found at Muchea Șesului (with a diameter between $1 \mathrm{~m}$ and $15 \mathrm{~m}$ and a 
depth from $0.5 \mathrm{~m}$ to $7 \mathrm{~m}$ ) or blind torrential valleys. In this area, at Nucșoara, in Măgura area, there are also two dolines, the larger one quartering Învârtita Lake and the other, Gaura Măgurii, is drained by a brook, with intermittent discharge.

For Moldova area, forms of relief created by plasters intercalated to the Miocene, on the space of Tazlău-Cașin Depression, from the north side of Valea Rea up to Bălăneasa valley, under the form of dolines, slopes and lapiès. They are isolatedly found in Carageaua Hill, in Săliște Hill, from the west side of Răchitiș village and in Chirtog Hill from Schitu valley (Brânduș, 1981). Lapiès were signalled at the upper part of Perchiu Hill (Grozavu, 2003). An incipient doline and lapiès are also present at south side of Trotus,, in Podeac Hill, from the south side of Bogdănești locality (Mară, 1999; Grozavu, 2003). The presence of a cave as karstic form was also signalled. It was discovered by professor R. Pușcariuc, having a length of about $30 \mathrm{~m}$, is positioned on the forefront of the terrace of $80 \mathrm{~m}$, on the left side of Oituz, off Filipești village (Grozavu, 2003).

\subsection{Research methods}

The research of the corresponding perimeter was carried out by direct observation, topographical survey and plotting. It was considered to obtain a topographic plan at the scale 1:1000, the mention of relief fragmentation depth, both along Gherasim valley, as well as related to Nistoroaia valley from the west side. This plan was used to locate the karstic interest objectives, the 15 pedological profiles performed and the limits were drawn as regards the extension of soil units, necessary for the appreciation of surface soil erosion classes. By the direct observation action, the extension of parental materials was delimited for the soils, which allowed considerations on the extension of submontane glacis, from the east of Ceir Peak.

\section{Natural factors}

\section{1. Tectonics and lithology}

The geotechnics of the perimeter is closely related to the evolution of flysch deposits and pericarpathian molasse (sandstone), from the area of Carpathian geosyncline, the foreland being the Moldavian Platform. The peri-carpathian unit is saddled at west by the external flysch, representing the autochthon for it (Băncilă, 1958; Mutihac, Ionesi, 1974).

Stiric movements (badenian) produced the thrust of Tarcău nappe, which covered a great part of the external flysch (Vrancea unit). The majority of areas uncovered by thrust become dry, and the sedimentation area from the east becomes the pericarpathian foredeep, which shall be filled by neogene sediments. Their diversity (conglomerates, freestones, clays, evaporites, etc.) expresses the rhythmicity of sedimentation intensity. They are composed of rock fragments, with variable dimensions and course and an uneven cementing (Săndulescu, 1962). 
Moldavian movements from the end of Volhynian intensely folded the deposits from the foredeep and generated a thrust to the molasse, with the entire structure of flysch layers from the west of foreland margin. At this moment begins the edification as land of Subcarpathians, which during Volhynian and Basarabian transformed into land, in contact with Sarmatian Sea from the east. In this large area of dry contact, a succession of adjoint deltas were formed, under the action of river that were descending from the Carpathians, the future piedmont between orogen and the platform.

The Walachian movements from the lower Pleistocene (Liteanu, Ghenea, 1967), the entire molasse area was edified as land. Tazlău - Caşin depression acquires the current morphological appearance by the occurrence and erection of Pietricica Crest and Ouşorul Massif, fact that allowed the organisation in the depression of the hydrographical system of Tazlău at the north and of Oituz at the south, all tributary to Trotuș. The formation of this hydrographical basin represents the start up of modelling processes within the entire subcarpathian space, being initially removed the piedmontane deposits, then there was passed to the modelling of molasse deposits.

The lithology of surface deposits was identified during the execution of soil profiles, being identified four categories of rocks, their extension having hallmarked the soil cover, influencing especially the physical and chemical characteristics, represented by:

- plasters, extended compactedly on the area of $870 \mathrm{sq} \mathrm{m}$, on Nistoreasa Peak and being mixed with other rocks, on the area of de $490 \mathrm{sq} \mathrm{m}$, on the south bevel of the natural levee;

- the clays represent the most extended rock from the researched perimeter, with compact extension in the basin of the valley, upstream the natural levee, where they occupy 5.98 ha and, being mixed with other rocks, on the area of 8820 sq $\mathrm{m}$, on the south bevel of the natural levee:

- calcareous freestones, present only on the south bevel of the natural levee, where they extend on $490 \mathrm{sq} \mathrm{m}$;

- fine skeleton clays, present only in the upper basin of the valley, in the space from which the submontane piedmont was not completely removed.

\section{2. Geomorphology}

Gherasim torrential valley is positioned on the south prolongations of Berzunți Crest and it is drained towards Trotuş River, through Vâlcele brook. The genesis of subcarpathian relief was greatly produced in Quaternary, when the removal of the greatest part of piedmontane cover took place, the further evolution of forms being produced under the influence of neotectonic movements and of lithologic variety, 
within the tectonic compartments and on hydrographical basins, general feature characteristic to new regions exposed to a violent denudation as the Subcarpathians, to the relief dynamics and the land use potential (Badea, 1983).

The evolution of Gherasim valley in Quaternary. The distribution of surface lithological materials and the soil erosion condition highlight the intensity of denudation processes, triggered by the local level of Trotus valley. The land inflexions and the low harshness of lithological deposits allowed the installation and rapid depthing of Vâlcele valley, on the areas occupied by the Pleistocene piedmont. The continuity of denudation process produced the removal of the greatest part of piedmontane deposits and the denudation unearthed massive plaster deposits, where crests are individualised, having determined direction changes for some secondary valleys, tributary to Vâlcele brook. The Pleistocene piedmont preserved in the upper third part of Gherasim valley, where the character of the valley is consequent and the present lithology is represented by fine clays with fragments of uncarbonated freestones. These deposits extend from the west limit of torrential basin up to the altitude of $460 \mathrm{~m}$. The lands from the east side of Pleistocene piedmont are occupied by clays, plasters and freestones that got outside because of intense denudation. After the erosion of piedmontane deposits, the transfer direction of denuded materials was kept, towards Vâlcele brook, but the overlaying of plaster crests on the left side of the valley determined the change towards the south of course orientation. The denudation processes and the depth of the valley continued until the thalweg of the valley reached the benchmark of 410 $\mathrm{m}$, where it intercepted a thick layer of about $10 \mathrm{~m}$ of plasters and freestones, and the fissuration of these rocks allowed the infiltration of rain waters into the rock bank, through a sink-hole which is positioned at the altitude of $401 \mathrm{~m}$. The northern slope of the natural levee has a height of $9 \mathrm{~m}$. The waters infiltrated into the sinkhole reappear, in a Karstic intermittent spring, below the south slope of the natural levee, at benchmarks of $373 \mathrm{~m}$, the underground route having an altitudinal fall of $28 \mathrm{~m}$. 


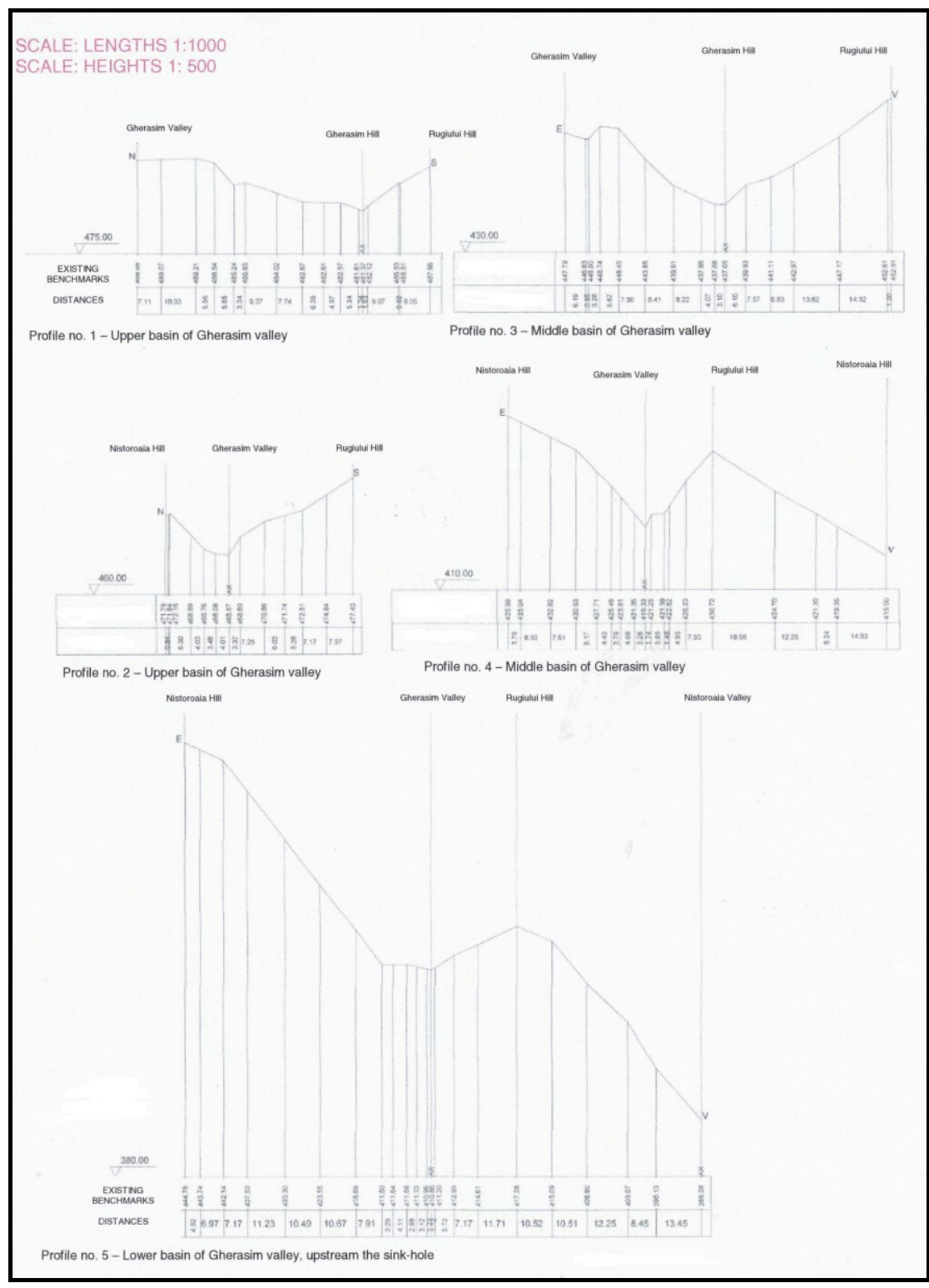

Fig. 3. Transversal profiles 


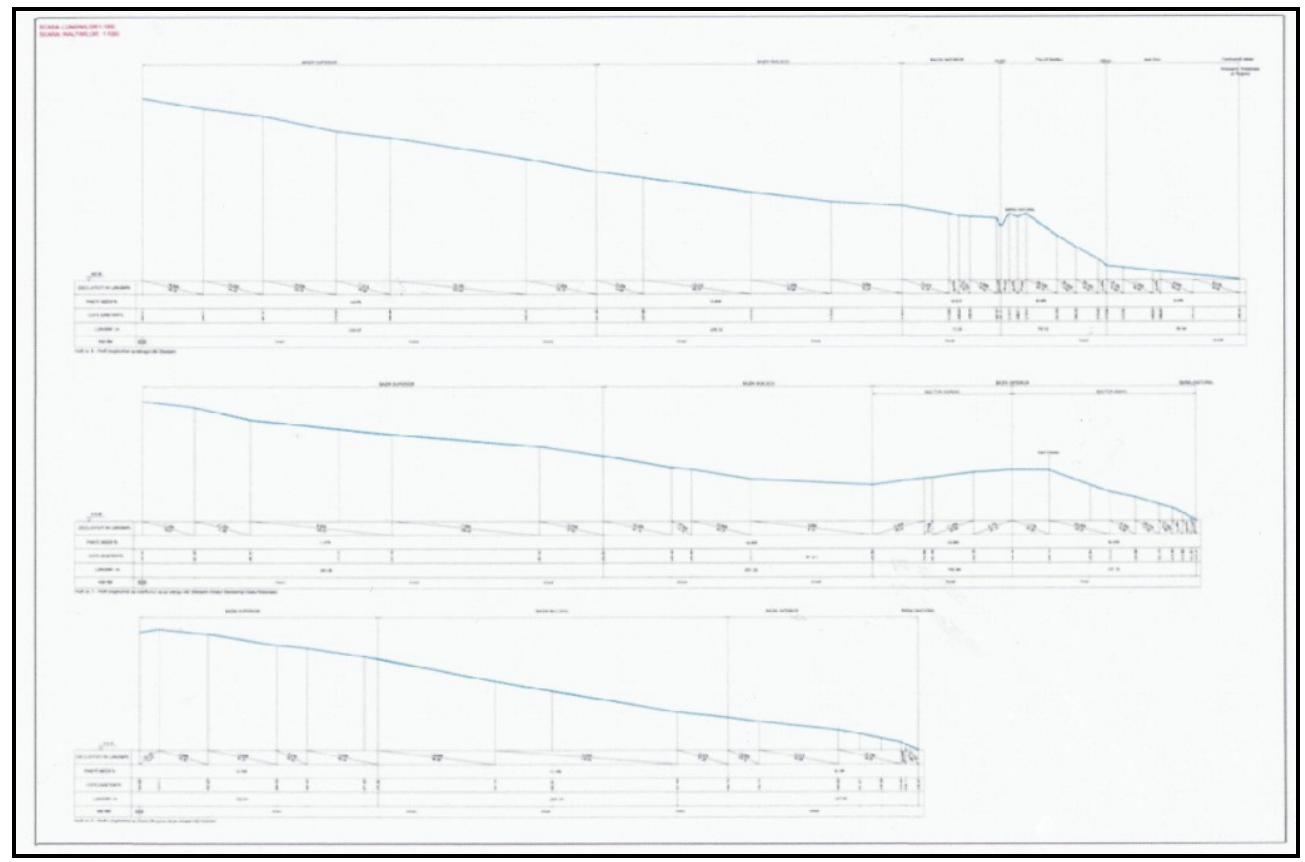

Fig. 4. Longitudinal profiles

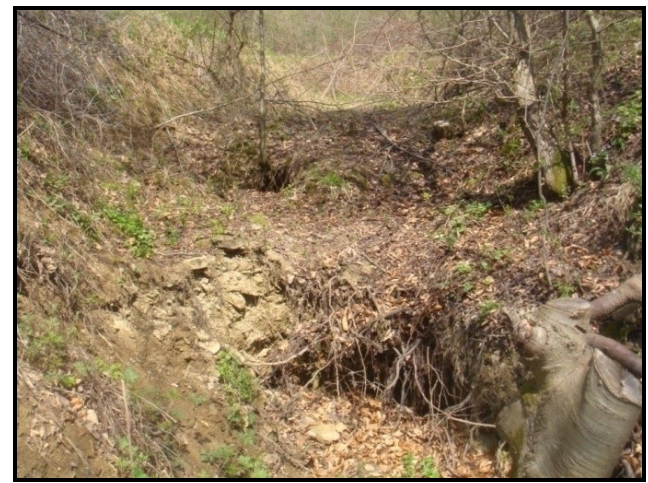

Fig. 5. Thresholds of $0.1-1 \mathrm{~m}$ on the talveg Gherasim valley, upstream the sink-hole.

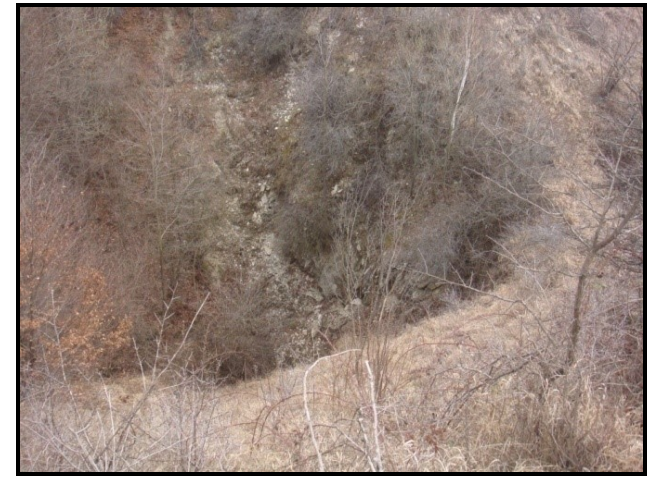

Fig. 6. The doline developped of the natural levee.

Morphography. The crests delimiting Gherasim valley are secondary, are contoured from the upper basin and they detached from the surface of the piedmontane glacis, as a result of depthing of valley thalweg. On the left side of the valley, the interfluvial crest is evenly reduced towards east, in the upper basin, in 
Gherasim Hill, with an average tilt of over $11 \%$, then the slope is maintained at over $10 \%$ in the entire saddle between Gherasim Hill and Nistoroaia Peak and it has the average value of over $26 \%$ between Nistoroaia Peak and the natural levee of plasters. The crest on the right side of the valley (Rugiului Hill) has a permanent altitudinal decrease, but the lowest slopes are found in the upper basin (almost 13 $\%$ ) and the highest tilts are found in the lower basin, of over $18 \%$ (Fig.no.3, Fig. no.4). Gherasim valley is a torrential valley, with discharge only during rainy periods, for which the thalweg slope has values of over $15 \%$ in the upper basin, of $10 \%$ in the middle basin and of over $20 \%$ in the lower basin, upstream the natural levee, where more ridges are present with unevenness of almost one meter each (Fig. 5, Fig. 6). Downstream the Karstic intermittent spring, the slope is only of 10 $\%$. The connection between the crests and the valleys is achieved through versants, with expositions imposed by the orientation of crests, which are affected by the areolar erosion and partially by the depth erosion, small failures and landslips.

Morphometry. The basin of Gherasim torrential valley is altitudinally disposed between $500 \mathrm{~m}$ at the upper limit, towards Ceir Peak and $364 \mathrm{~m}$ at the confluence of Gherasim, Nistoroaia and Rugiului brooks. If the highest altitudes are present in the piedmont space, in the middle and lower basin, the highest altitudes are present on the crests which have plasters in their axis.

The depth of relief fragmentation. It must be presented only for the sector upstream the natural levee. If in the upper basin it has values of 6-7 $\mathrm{m}$ on both valley versants, in the middle sector they have the tendency to increase, exceeding $12 \mathrm{~m}$ towards Gherasim Hill and $18 \mathrm{~m}$ towards Rugiului Hill, in the saddling area between Gherasim Hill and Nistoroaia Peak, it comes back to over $10 \mathrm{~m}$ and upstream the natural levee, the depth of fragmentation has approximately $8 \mathrm{~m}$ towards Rugiului Hill and almost $34 \mathrm{~m}$ towards Nistoroaia Peak. The fragmentation depth from Rugiului Hill towards Năzărioaia valley is of almost 30 $\mathrm{m}$. The presence of the natural levee protected the upstream lands, while on Nistoroaia valley, the free denudation determined the descent of the thalweg by approximately $25 \mathrm{~m}$, with the corresponding extension and of the adjacent versants.

Land slope. Totally, the basin of Gherasim torrential valley is positioned on inclined lands between the values of $5-15 \%$, present on the saddle from the northern interfluve, up to values of $95 \%$, found on the versants at the south of the natural levee. This element, together with the vegetal cover and human activity, have a deciding importance in the determination of soil preservation condition.

The morphogenesis is determined both by the characters and processes imprinted on the lithological structures, as well as by the action of climate, hydrological and anthropic factors (Fig. 7). 


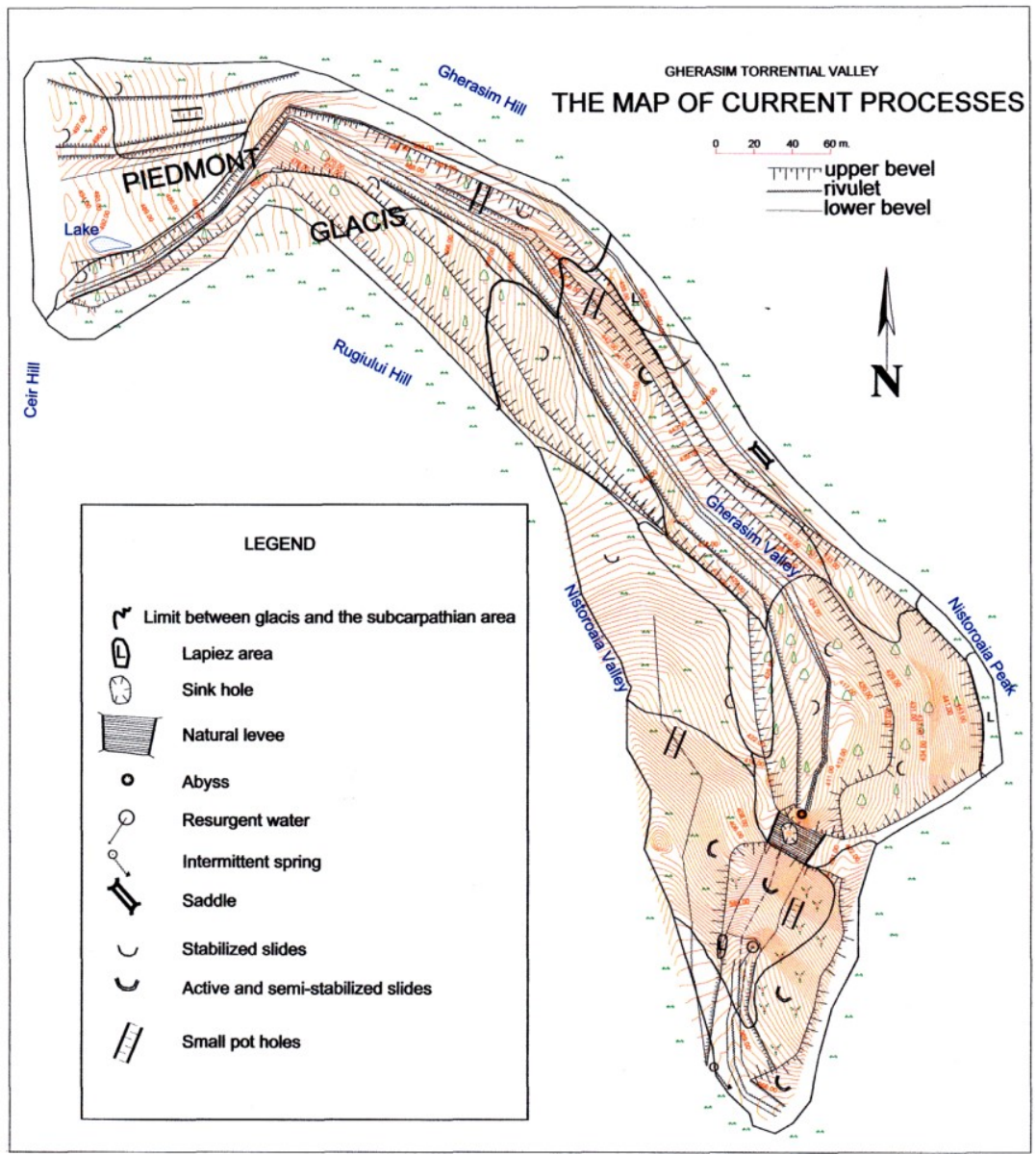

Fig. 7. The map of current processes.

The petrographic relief, determined by the presence of plasters, is Theimportant for the entire Moldavian subcarpathian area. The intercalation of plasters layers in the neogene molasse, sometimes with important extensions, allows, on the Gherasim torrential valley area, the formation of a plaster relief, represented by lapiès, doline, natural levee, sink-hole, Karstic intermittent spring, intermittent character springs. In the entire torrential basin, no springs are found.

The lapiès (Fig. 8) have lengths of the most 10-15 cm and depths of 3-5 mm and they are positioned on appearances of plasters from Gherasim Hill (north-west of the saddle), in Nistoroaia Peak and on the versant at the south of the natural levee. The low harshness of these rocks makes that the denudation destroy rapidly 
the walls bordering the lapiès.

The doline (Fig. 9) was identified in the space of the natural levee, it has a diameter of $9 \mathrm{~m}$ and a depth of $2 \mathrm{~m}$, and it seems to be formed by the dissolution processes taking place because of quartering of waters discharged from the versants.

The natural levee was formed because of the failure of the torrential debit to penetrate the massive plaster and freestone layer and the existence of cracks in the lithological deposits allowed the infiltration of pluvial waters in a sink-hole positioned at the north side of the natural levee.

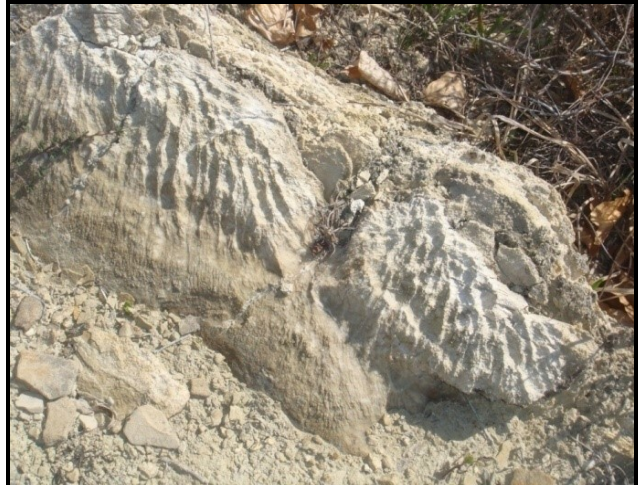

Fig. 8. Lapiès

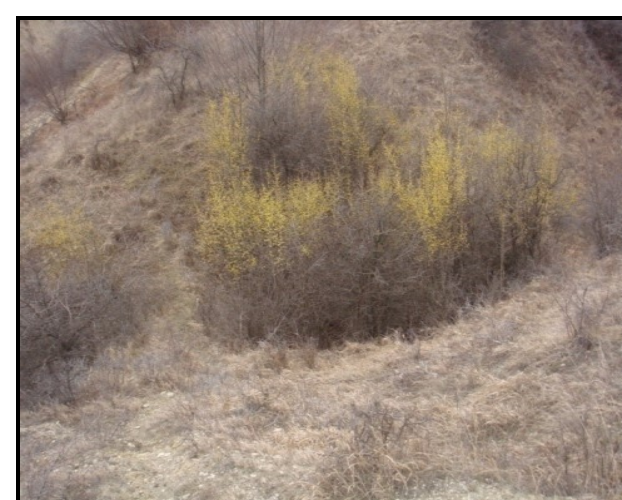

Fig. 9. Te doline developed on the natural levee

By denudation and suffosion, the altitudinal position of the sink-hole became deeper, thing that determined the creation of the northern wall of the natural levee, with a height of $9 \mathrm{~m}$ at present. The natural levee protected the lands upstream it, aspect which is obvious if we compare the altitude of thalwegs in the two torrential valleys, Gherasim and Nistoroaia (Fig. 10). The sink-hole, situated under the wall upstream the natural levee, represents a gap of about $15 \mathrm{~cm}$ in width, from where the water infiltrates underground, at the altitude of $401 \mathrm{~m}$. The Karstic intermittent spring is positioned under the south wall of the of $373 \mathrm{~m}$, the water travelling in the interior of the natural levee an altitudinal difference of 28 metres. 


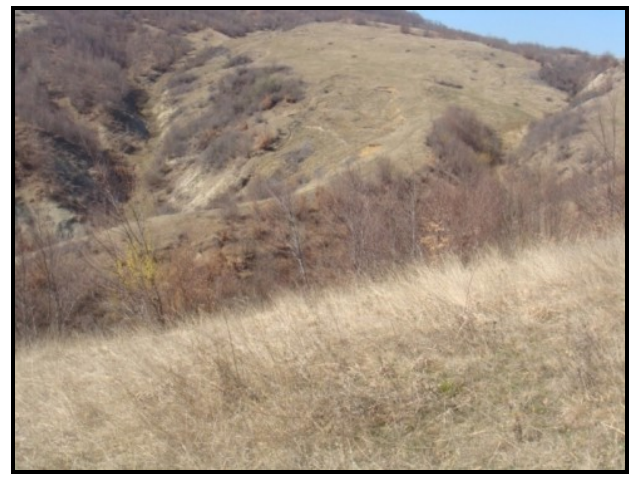

Fig. 10. Difference of depthing of

Gherasim and Nistoroaia valleys

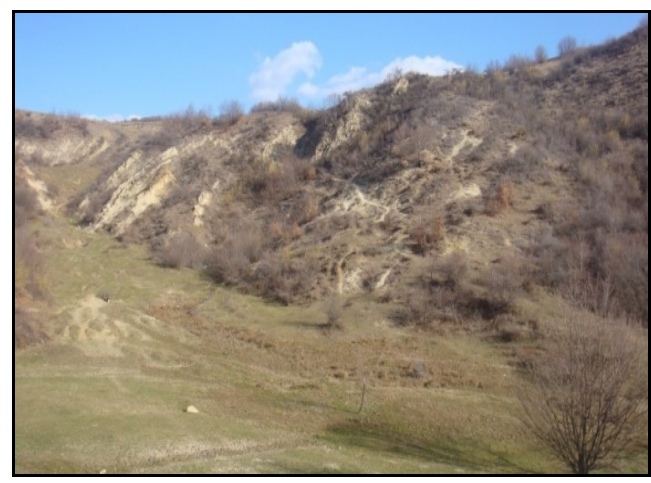

Fig. 11. Left versant of Nistoroaia brook

Within the researched perimeter, we also found an intermittent spring, on the thread of Nistoreasa valley, which has a continuous flow during rainy periods, with variable flow rate, and during draught periods it is discontinuous, with water ejections at the interval of 2-3 seconds.

The fluvio-denudational relief is the most extended relief type from the natural levee, being the product of the denudation process action by which there were formed, within the sculptural relief, interfluvial apexes and crests and versants, and the accumulation relief is represented by Pleistocene glacises and current glacises. The versant processes within the perimeter are represented especially by surface erosion, depth erosion and landslips (Fig.11).

The surface erosion completely affects the surface of this basin (of $8.523 \mathrm{ha}$ ) and it is generated by the discharge of pluvial waters at the soil surface, on slopes. The extension of erosion classes, taken over from the areas occupied by soils is the following:

- low erosion, present on 1.977 ha, namely $23.19 \%$;

- the moderate erosion, occupying 1.992 ha, namely $23.37 \%$;

- strong erosion, extending on 3.148 ha, namely $36.94 \%$;

- very strong erosion, occupying 0.426 ha, namely $5.0 \%$;

- excessive erosion, resent on 0.98 ha, namely $11.5 \%$ of the total eroded lands (Fig. 13).

It can be noted that the weakly-moderately lands occupy about $46.5 \%$, and the strongly, very strongly and excessively eroded lands have a significant weight, against the entire preponderance of grasslands and forests. The area of lands with very strong erosion, situated at the north-west of the basin, still keeps the routes of the baulks, which were delimitating the lots of grass lands, areas where the uncontrolled pasturage and deforestations of forest stand, have determined the occurrence of argic B horizon and the creation along the lots, in the middle area, of 
some small gullies, by water concentrations, at the level of each lot of previous use.

Depth erosion. As a whole, the entire area of Gherasim torrential valley can be classified as an active, deep, partially stabilized sink-hole. The perimeters actively affected by the depth erosion, under the form of gullies with the depth of $0.5-1 \mathrm{~m}$ are located in the lower and upper basins of the valley, where they occupy the area of 2.546 ha, namely almost $30 \%$ of the researched perimeter. The lands in the upper basin are occupied by forests and those in the lower basin, at the south of the natural levee, are barrens. The forms under which they manifest are gullies, the lands having sometimes the appearance of badlands (Fig. 12). The area affected by depth erosion represents:

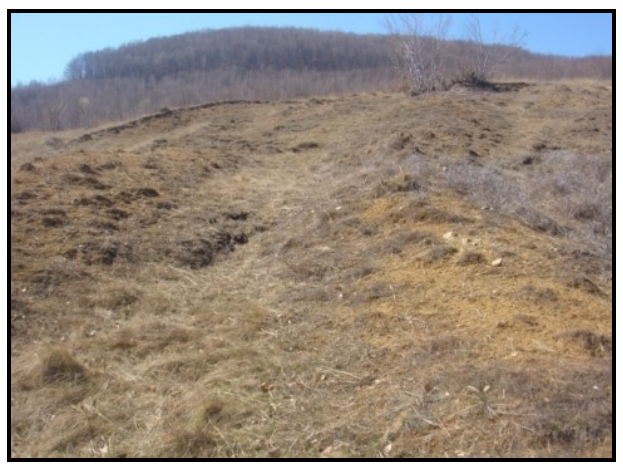

Fig. 12. Badlands areas in the upper basin of Gherasim torrential valley.

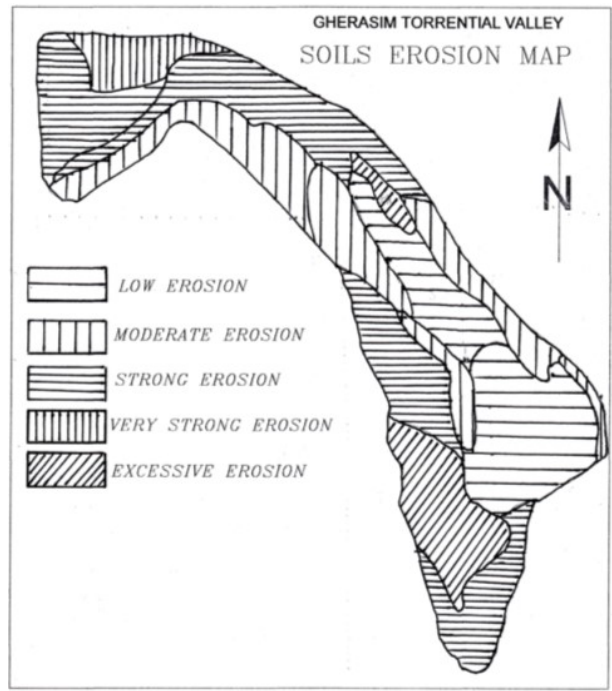

Fig. 13. Soils erosion map. 
Landslips are important because they change the form of the versant and the hydrological regime of it, generating mixtures of soil horizons. The great extension of clays, the exceeding regime of precipitations, the land tilting and the current use of lands offer optimal conditions for the production of landslips.

As a whole, in the basin area, the landslips extend on 6.308 ha, namely $74 \%$ of the total. According to the observations from the field, the landslips have the sliding bed situated at 1-2 $\mathrm{m}$ in depth and, according to the form and stability degree, three sliding classes have been separated:

- landslips in stabilized waves, present on 4.731 ha, namely $55.50 \%$;

- landslips in semi-stabilized waves, occupying 0.597 ha, namely $7.0 \%$;

- landslips in semi-stabilized waves, locally with failures, extended on 0.980 ha, namely $11.50 \%$, of the entire basin. Locally, between the landslip waves, small temporary lakes are present.

Within the areas affected by landslips, we can notice the great weight of lands with stabilized slips $(75.0 \%)$ and the lands with semi-stabilized slips extend on $25.0 \%$.

Depth erosion. As a whole, the entire area of Gherasim torrential valley can be classified as an active, deep, partially stabilized sink-hole. The perimeters actively affected by the depth erosion, under the form of gullies with the depth of $0.5-1 \mathrm{~m}$, are located in the upper and lower basins of the valley, occupying the area of 2.546 ha, namely almost $30 \%$ of the researched perimeter. The lands in the upper basin are occupied by forests and those in the lower basin, at the south of the natural levee, are barrens.

The forms under which they manifest are gullies, the lands having sometimes the appearance of badlands. The area affected by depth erosion represents:

- small gullies with rare density, on 1.566 ha, namely $18.37 \%$ and

- small gullies with high density, occupying 0.980 ha, namely $11.50 \%$.

The glacises are forms of accumulation of eroded materials from the versants. According to age and petrographic composition, two categories of glacises were distinguished in Tazlău Depression (Brânduş, 1981):

- old, formed in Pleistocene, strongly fragmented and eroded, positioning the upper basin of the torrent, where in the fine clay mass are present fragments of skeleton with low course degree. This glacis is present in the erosion destruction phase.

- new, Holocene, with material deposits only on the bottom of Gherasim valley, which has widths of 1-3 m, where low silting processes take place. The slope of the thalweg, of over $10 \%$ on the entire route, ensures almost the entire transportation of the solid debit towards Vâlcele brook. 


\section{Conclusions}

The catchment basin of Gherasim valley is situated on the submontane glacis below Ceir Peak and it is drained towards Vâlcele brook, left affluent of Trotuş. By the movements from the end of lower Pleistocene, the entire subcarpathian area was edified as land. By the partial erosion of Pleistocene piedmont, in the middle area of the hydrographical basin of Gherasim valley, crests composed of plasters have been highlighted.

Gherasim valley, having its outlet in Vâlcele valley, has its origin on the Pleistocene piedmont, initially having a west-east direction and, encountering in its route Gherasim Hill and Nistoroaia Peak that have plasters in their axes, changes its direction gradually, towards the south. On this route, at west from Nistoroaia Peak, it reached to a harder layer, composed of plasters and freestones, it could not penetrate. The water taken over from its own basin found cracks in the layers upstream the plasters, infiltrated into the rocks and at present appear under the form of a Karstic intermittent spring, at the south of the natural levee, at an altitudinal difference from the sink-hole of 28 meters. These conditions allowed the formation of some forms of plaster relief, represented by a natural bridge, unique in Moldavia, doline, sink-hole, Karstic intermittent spring, lapiès or intermittent debit spring.

The evolution of the relief in the area was influenced by the presence of the natural levee, which protected the lands upstream, while, on Nistoroaia valley in the west vicinity, the free denudation determined the descent of the thalweg by about $25 \mathrm{~m}$, with the corresponding extension of the adjacent versants.

Gherasim torrential valley is affected by active denudation processes, represented by the surface erosion in the entire basin, of active depth erosion on 30 $\%$ of the basin and by landslips, locally with failures, which have a weight of $74 \%$.

The relief identified in the researched area has scientific importance in order to highlight the forms of relief existing at the level of the country, have didactic significance because they are found on a restrained space and with a good accessibility and measures for the preservation, protection of the lands upstream the natural levee are imposed against the intense denudations, on vicinity.

It is necessary that it receive the status of protected area as geomorphologic site of national importance.

The preservation of these forms of relief can be achieved by measures referring to:

- stop of pasturage in the lower basin of Gherasim valley, the removal of knobs and the removal of subforest stand in order to bring the forest to the level of highforest;

- forestation of areas that are in unproductive use at present, with the 
performance of works protecting the terrestrial area for lying fallow purposes;

- levelling works, surface drainage and over-seeding, for the slipped lands;

- concreted steps on the last $200 \mathrm{~m}$ upstream the sink-hole, for the preservation of balance, both for the versants and for the thalweg;

- the controlled discharge of pluvial waters, that are accumulating upstream the natural levee, having the primordial purpose of protecting the natural levee;

For the development of these lands for tourism purposes, it is necessary to be achieved:

- slab paths which ensure the circulation of tourists towards the natural levee, sink-hole, Karstic intermittent spring and the areas of lapis presence;

- the arrangement of drain channel for the waters on the inferior route of Nistoroaia valley and of the current spring, with a table and benches for the stops;

- periodical control for the maintenance of cleanness in the area;

- as mandatory activity in the schools of Târgu Ocna town, travels in the area are necessary, to know the travel interest or educational objectives.

\section{References}

Brânduș C. (1981) - Tazlău Subcarpathians, geomorphological study. RSR Academy Publishing House, Bucharest.

Grozavu A. (2003) - Subcarpathians between Trotuş and Șușița, physicogeomorphological study. Corson Publishing House, Iași.

Mară M. (1999) - Tazlău Caşin Depression, pedogeographic study. Corson Publishing House, Iași.

Naum T. and Grigore M. (1974) - Geomorphology. Didactic and Pedagogical Publishing House, Bucharest.

Posea Gr. and collab.(1976) - Geomorphology. Didactic and Pedagogical Publishing House, Bucharest.

***(1983) - Geography of Romania, volume I. RSR Academy Publishing House, Bucharest.

***(1992) - Geography of Romania, volume IV. Romanian Academy Publishing House, Bucharest. 